\title{
RADIOCARBON AND BLUE OPTICALLY STIMULATED LUMINESCENCE CHRONOLOGIES OF THE OITAVOS CONSOLIDATED DUNE (WESTERN PORTUGAL)
}

\author{
M I Prudêncio ${ }^{1,2} \bullet \mathrm{R} \mathrm{Marques}^{1} \bullet \mathrm{L} \mathrm{Rebelo}^{3} \bullet \mathrm{G} \mathrm{T} \mathrm{Cook}^{4} \bullet \mathrm{G} \mathrm{O}$ Cardoso $^{1} \bullet \mathrm{P} \mathrm{Naysmith}^{4} \bullet$ \\ S P H T Freeman ${ }^{4} \bullet$ D Franco $^{1} \bullet$ P Brito $^{3} \bullet$ M I Dias $^{1}$
}

\begin{abstract}
The dune of Oitavos, the underlying paleosol, and Helix sp. gastropod shells found within the paleosol were dated using a combination of radiocarbon and blue optically stimulated luminescence (OSL). The organic component of the paleosol produced a significantly older age $(\sim 20,000 \mathrm{cal} \mathrm{BP})$ than the OSL age measurement $(\sim 15,000 \mathrm{yr})$, while ${ }^{14} \mathrm{C}$ age measurements on the inorganic component and the gastropods produced ages of $\sim 35,000 \mathrm{yr}$ and $\sim 34,000 \mathrm{yr}$, respectively. Rareearth element analyses provide evidence that the gastropods incorporate geological carbonate, making them an unreliable indicator of the age of the paleosol. We propose that the ${ }^{14} \mathrm{C}$ age of the small organic component of the paleosol is also likely to be unreliable due to incorporation of residual material. The OSL age measurement of the upper paleosol $(\sim 15,000 \mathrm{yr})$ is consistent with the age for the base of the dune $(\sim 14,500 \mathrm{yr})$. The younger OSL age for the top of the dune $(\sim 12,000 \mathrm{yr})$ suggests that it was built up by at least 2 sand pulses or that there was a remobilization of material at the top during its evolution, prior to consolidation.
\end{abstract}

\section{INTRODUCTION}

The dune of Oitavos is one of several consolidated dunes located on the coast near Serra de Sintra, in the central part of the west Portuguese Atlantic coast (Marques and Ramos 1983), and is classified as a "geomonument." The dune is built up on top of a sandy soil where Helix sp. gastropods are present. Moniz (1992) quotes a radiocarbon age of 31,700 (+1700/-1400) BP for this soil, which means that the dune should be younger than that age; however, no dating has been carried out on the dune itself.

In this work, both the paleosol and the Oitavos dune were dated. The paleosol was ${ }^{14} \mathrm{C}$ dated using both accelerator mass spectrometry (AMS) (Helix sp. gastropods and organic carbon component) and liquid scintillation counting (LSC) (inorganic carbon component), and by optically stimulated luminescence (OSL). The bottom and top of the consolidated dune were also dated by OSL. Chemical and mineralogical characterization of different samples from the dune, the paleosol, and the paleosol snails were also carried out using instrumental neutron activation analysis (INAA) and Xray diffraction $(\mathrm{XRD})$.

In addition to dating the Oitavos consolidated dune and the underlying soil, this work aimed to compare different dating techniques and methodological approaches, including rare-earth element geochemistry and mineralogy as tools to evaluate the degree of "dead" carbon in the snails from the limestone environment.

\section{STUDY AREA AND SAMPLING}

The Oitavos consolidated dune is located near Serra de Sintra, close to Guincho (Portugal), on top of a marine abrasion platform developed on Cretaceous carbonate rocks (Figure 1). The dune was built up on a sandy soil where Helix sp. gastropods are present. Currently, the Oitavos dune mea-

\footnotetext{
'Instituto Tecnológico e Nuclear, EN 10, Sacavém, 2686-953, Portugal.

${ }^{2}$ Corresponding author. Email: iprudenc@itn.pt.

${ }^{3}$ Departamento de Geologia Marinha, Instituto Nacional de Engenharia, Tecnologia e Inovação (INETI), Lisbon, Portugal.

${ }^{4}$ SUERC, Scottish Enterprise Technology Park, East Kilbride, G75 0QF, United Kingdom.
} 
sures $\sim 500 \mathrm{~m}$ long by $100 \mathrm{~m}$ wide, with a height reaching $25 \mathrm{~m}$. It probably corresponds to part of a larger sand body that was partially consolidated.

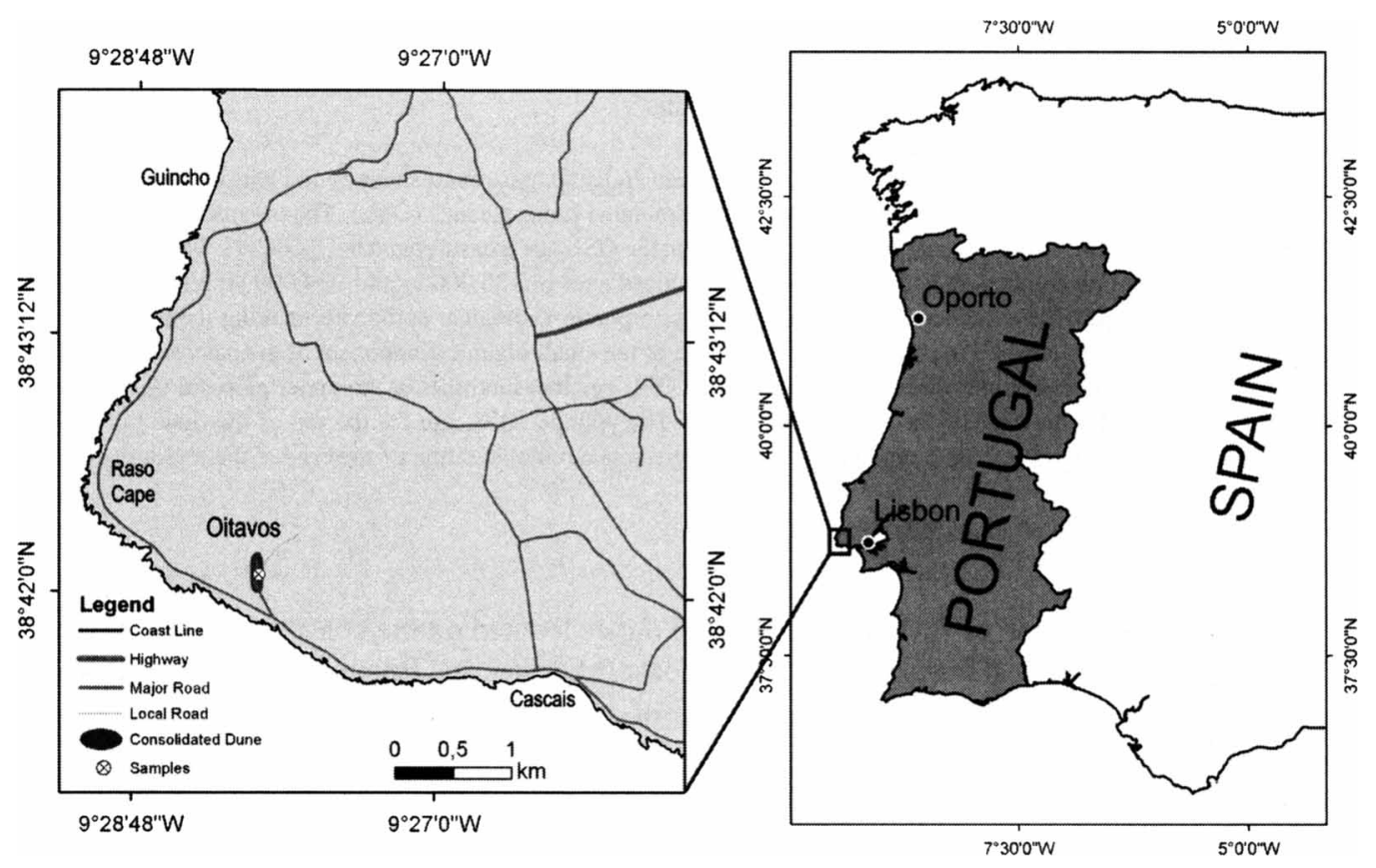

Figure 1 Location of the study area

Dune dismantling for the purpose of rock extraction created a good surface to observe the internal structure of the dune. Stratification dips mainly to the east, with an angle between $22^{\circ}$ and $42^{\circ}$, suggesting eolian transport to $\mathrm{N} 104^{\circ} \mathrm{E}$ (Rebêlo 2004). This value is significantly different from the present sand transport that occurs with a $\mathrm{N} 161^{\circ} \mathrm{E}$ direction (Rebêlo 1998). Lamination of sediments of different granularity is evident, ranging from fine to coarse sands. Quartz is the dominant mineral and the cement is calcareous (Moniz 1992).

Samples were collected on a vertical profile from the underlying paleosol to the top of the dune. Because both the paleosol and the dune are sandy units, the contact between them is not sharp and neat. In the field, a separation "layer" can be observed, raising questions about its origin and creating some uncertainty regarding to which unit (dune or soil) it belongs. To be sure that sampling was made in the paleosol or in the dune, this level was avoided. Paleosol (P) and snail (S) samples were collected for ${ }^{14} \mathrm{C}$ and OSL dating from the uppermost part of the soil. Dune samples were collected for OSL dating. Sample D-1 corresponds to the bottom of the dune above the P sample, and D-2 was collected at a horizontal distance of $\sim 1 \mathrm{~m}$ from D-1. Sample D-3 was collected at the top of dune (Table 1).

Table 1 Samples and methods used for dating.

\begin{tabular}{llll}
\hline & \multicolumn{2}{c}{${ }^{14}$ C dating } & \\
\cline { 2 - 3 } Samples & AMS (SUERC) & LSC (ITN) & Luminescence dating (B-OSL) (ITN) \\
\hline Snails (S) & $\mathrm{X}$ & $\mathrm{X}$ & $\mathrm{X}$ \\
Paleosol (P) & $\mathrm{X}^{\mathrm{a}}$ & $\mathrm{X}$ \\
Dune (D-1, D-2, D-3) & & & \\
\hline
\end{tabular}

${ }^{\mathrm{a}}$ With pretreatment. 


\section{RADIOCARBON DATING}

\section{AMS at SUERC}

The organic component of the paleosol sample was dated. This was separated from the bulk of the sample, which was inorganic, by flotation. The sample was then heated in $1 \mathrm{M} \mathrm{HCl}$ for several hours, filtered, washed in reverse osmosis water, and dried. It was then combusted in an evacuated, sealed quartz tube using copper oxide as the oxidant and silver foil to react with and remove gaseous contaminants (mainly halides). The tube was opened under vacuum, the $\mathrm{CO}_{2}$ recovered and cryogenically purified, and a 2-mL aliquot was converted to graphite according to the method of Slota et al. (1987). A further aliquot was retained for $\delta^{13} \mathrm{C}$ analysis on a VG SIRA 10 isotope ratio mass spectrometer using NBS standards 22 (oil) and 19 (marble) to determine the 45/44 and 46/44 atomic mass ratios, from which the $\delta^{13} \mathrm{C}$ value was calculated.

A large piece of snail shell was selected for analysis. The sample was first cleaned in a sonic bath and washed thoroughly. It was then hydrolyzed using a limited quantity of $1 \mathrm{M} \mathrm{HCl}$ to remove the outer $\sim 25 \%$, then hydrolyzed under vacuum using an excess of $1 \mathrm{M} \mathrm{HCl}$, and the $\mathrm{CO}_{2}$ collected and cryogenically purified. Graphitization and $\delta^{13} \mathrm{C}$ analysis were as described above.

The graphite samples were pressed into aluminum holders and analyzed at the SUERC AMS facility (NEC 5MV terminal voltage), Scotland, with carbon in the 4+ charge state. Graphite targets produced from the modern reference standard (NIST oxalic acid II [SRM-4990C]), interglacial wood (as à background), and known-age materials (dendrochronologically dated wood and barley mash from TIRI) were also run in the batch to ensure the quality of the data.

\section{Liquid Scintillation Counting at ITN}

The carbonate fraction of the paleosol was ${ }^{14} \mathrm{C}$ dated by liquid scintillation counting (LSC) at the Instituto Tecnológico e Nuclear (ITN). Since the samples had low organic matter content, they did not undergo any pretreatment. They were hydrolyzed in the benzene synthesis line using $\mathrm{HCl}$, and the $\mathrm{CO}_{2}$ evolved was reacted with molten lithium to form lithium carbide, which was cooled and reacted with water to produce acetylene. The acetylene was then converted to benzene by cyclotrimerization using a chromium-based catalyst. The ${ }^{14} \mathrm{C}$ content was measured using a Packard TriCarb $2770 \mathrm{TR} / \mathrm{SL}$, together with 2 background samples and 1 modern sample synthesized from NIST oxalic acid II.

\section{LUMINESCENCE DATING}

Three dune samples were collected in Inox cylinders, avoiding any contact with light following collection. At all sampling sites, gamma measurements were made in situ using a portable Gamma nanoSpec. The samples were opened inside the luminescence laboratory at ITN, and the external material rejected.

Samples were dried and sieved to obtain the fraction between 160 and $100 \mu \mathrm{m}$. This fraction was treated with $10 \% \mathrm{HCl}$ and $30 \% \mathrm{H}_{2} \mathrm{O}_{2}$ to remove organic matter and carbonates. Feldspars were removed by leaching with hydrofluoric acid for $80 \mathrm{~min}$ and $10 \mathrm{~min}$ with $\mathrm{HCl}(10 \%)$, and the solution dried at $50^{\circ} \mathrm{C}$. The coarse quartz grains were placed on Inox disks, held with silicone spray.

The measurements were made using a RIS $\varnothing$ TL-DA-15 reader. Optically stimulated luminescence (OSL) was made by blue LEDs using a halogen lamp and an optical filter (Hoya U340) linked to a photomultiplier (EMI $9635 \mathrm{QA}$ ). The $\beta$ irradiation was done by a $25-\mathrm{mCi}{ }^{90} \mathrm{Sr} /{ }^{90} \mathrm{Y}$ source (Richter et al. 2003). Data obtained were treated using appropriate software (Analyst, RISO). 


\section{CHEMICAL AND MINERALOGICAL ANALYSES}

\section{INAA and XRD}

Rare-earth element abundances in the paleosol ( $\mathrm{La}, \mathrm{Ce}, \mathrm{Nd}, \mathrm{Sm}, \mathrm{Eu}, \mathrm{Tb}, \mathrm{Yb}, \mathrm{Lu})$, snails, and dune samples were determined by instrumental neutron activation analysis (INAA) at ITN. Aliquots of about $1 \mathrm{~g}$ of powder were dried in an oven at $110^{\circ} \mathrm{C}$ for $24 \mathrm{hr}$ and stored in a desiccator until the samples could be weighed for irradiation. The same procedure was done for the reference materials used (soils GSS-4 and GSS-5 from the Institute of Geophysical and Geochemical Prospecting, China). The reference values were taken from data tabulated by Govindaraju (1994).

All powdered samples (samples and standards) were prepared by weighing 200-300 mg into clean high-density polyethylene vials. A long irradiation time $(7 \mathrm{hr})$ was performed in the core grid of the Portuguese Research Reactor at a thermal flux of $3.34 \times 10^{12} \mathrm{n} \mathrm{cm}^{-2} \mathrm{~s}^{-1} ; \phi_{\mathrm{epi}} / \phi_{\mathrm{th}}=1.4 \% ; \phi_{\mathrm{th}} / \phi_{\mathrm{fast}}=$ 12.1. Corrections for the spectral interference from uranium fission products in the determination of $\mathrm{Ce}$ and $\mathrm{Nd}$ were carried out according to Gouveia et al. (1987). Relative precision and accuracy were better than $5 \%$.

The X-ray diffraction patterns were obtained at ITN using a Philips diffractometer using $\mathrm{Cu} \mathrm{K} \alpha$ radiation at $40 \mathrm{kV}$ and $30 \mathrm{~mA}$.

\section{RESULTS AND DISCUSSION}

The results obtained by AMS for the paleosol (organic component) and by blue optically stimulated luminescence (B-OSL) for the paleosol and dune samples are given in Table 2. Results obtained for the snail shells (AMS) and the carbonate fraction of the paleosol (LSC) are shown in Table 3.

Table 2 Results obtained by ${ }^{14} \mathrm{C}$ (AMS) and OSL dating methods.

\begin{tabular}{llllll}
\hline Lab code & Sample code & Sample type & Dating method & $\delta^{13} \mathrm{C}(\% \circ)$ & Age BP $\pm 1 \sigma$ \\
\hline ITN-Lum-75 & D-3 & Dune & B-OSL & $n / a^{\mathrm{a}}$ & $11,880 \pm 537$ \\
ITN-Lum-74 & D-2 & Dune & B-OSL & $\mathrm{n} / \mathrm{a}$ & $14,363 \pm 1086$ \\
ITN-Lum-72 & D-1 & Dune & B-OSL & n/a & $14,454 \pm 834$ \\
ITN-Lum-73 & P & Paleosol & B-OSL & n/a & $15,270 \pm 665$ \\
SUERC-8362 & P & Paleosol & ${ }^{14}$ C AMS & -24.2 & $16,400 \pm 50$ \\
\hline
\end{tabular}

${ }^{a} \mathrm{n} / \mathrm{a}=$ not applicable.

Table 3 Results obtained by ${ }^{14} \mathrm{C}$ dating (AMS and LSC) of snail shells and the paleosol.

\begin{tabular}{llllll}
\hline Lab code & Sample code & Sample type & Dating process & $\delta^{13} \mathrm{C}(\%)$ & Age (BP) \\
\hline SAC-2065 & $\mathrm{P}$ & Paleosol $^{\mathrm{a}}$ & LSC & 0.48 & $34,830+1350 /-1150$ \\
SUERC-7673 & $\mathrm{S}$ & Snail shell & AMS & -6.9 & $33,900 \pm 300$ \\
\hline
\end{tabular}

aNo pretreatment.

The AMS result obtained for the paleosol $(16,400 \pm 50 \mathrm{BP})$, which has a low organic content of $\sim 1 \%$, calibrates to $19,800-19,440$ cal BP at $95.4 \%$ confidence and is therefore significantly older than the B-OSL age of $15,270 \pm 665 \mathrm{yr}$. This may be indicative of the inclusion of residual organic material when the paleosol formed.

The uncalibrated age of $33,900 \pm 300$ BP obtained by AMS for the Helix sp. land snails is significantly older than that obtained for the organic component of the paleosol $(16,400 \pm 50 \mathrm{BP})$. This excessive age for the snails could be expected since these organisms lived in a limestone environ- 
ment. In fact, this anomaly has been found in old and modern land snails in limestone geological contexts and is explained by the incorporation of ${ }^{14} \mathrm{C}$-free limestone into shell carbonate (Goodfriend and Stipp 1983). A radiometric ${ }^{14} \mathrm{C}$ age for the carbonate fraction of the paleosol sample produced an age of $34,830+1350 /-1150 \mathrm{BP}$ that is not statistically different from that of the shells.

The ${ }^{14} \mathrm{C}$ (LSC) date obtained previously by Moniz (1992) for the paleosol underlying the Oitavos dune $(31,700+1700 /-1400 \mathrm{BP})$ is similar to the results obtained in this work by ${ }^{14} \mathrm{C}$ dating (AMS and LSC) of snail shells and the inorganic fraction of the paleosol, indicating an overestimation of the date due to "old carbon" incorporation in the snails. The incorporation of old carbon during snail shell formation and burial is corroborated by geochemistry and mineralogy. Rare-earth contents and mineralogical composition of all samples are given in Tables 4 and 5 .

Table 4 Mineralogical phase proportions obtained by X-ray diffraction (XRD).

\begin{tabular}{ll}
\hline Sample & Mineral proportions \\
\hline Dunes & Quartz $>>\mathrm{CaCO}_{3}>$ Feldspars \\
Snails & Aragonite $>>\mathrm{CaCO}_{3}$ \\
Paleosols & Quartz $>$ Feldspars $>\mathrm{CaCO}_{3}$ \\
\hline
\end{tabular}

Table 5 Rare-earth element contents $(\mu \mathrm{g} / \mathrm{g})$ in paleosol, snail, and dune samples.

\begin{tabular}{lcllcc}
\hline & Paleosol & Snails & Dune-1 & Dune-2 & Dune-3 \\
\hline $\mathrm{La}$ & 7.91 & 1.65 & 2.35 & 5.18 & 8.1 \\
$\mathrm{Ce}$ & 14.4 & 1.49 & 4.17 & 10.1 & 15.2 \\
$\mathrm{Nd}$ & 6.92 & 0.978 & 2.13 & 5.04 & 8.25 \\
$\mathrm{Sm}$ & 1.28 & 0.259 & 0.463 & 1.04 & 1.68 \\
$\mathrm{Eu}$ & 0.273 & 0.0596 & 0.143 & 0.32 & 0.385 \\
$\mathrm{~Tb}$ & 0.184 & 0.0268 & 0.0773 & 0.153 & 0.238 \\
$\mathrm{Yb}$ & 0.518 & 0.0915 & 0.31 & 0.499 & 0.689 \\
$\mathrm{Lu}$ & 0.075 & 0.0107 & 0.0429 & 0.073 & 0.0972 \\
\hline
\end{tabular}

In Figure 2, the rare-earth element (REE) patterns of the snails and the paleosol, as well as of the dune samples, are shown. The REE content in the snail shells is lower compared to the paleosol. The REE patterns are similar, except for $\mathrm{Ce}$, which is strongly depleted in the snail shells. This negative Ce anomaly is characteristic of marine carbonate precipitates. Dissolved REEs, mainly in the trivalent state, are supplied by river waters to the ocean. River-water REE patterns are smooth but with a negative Eu anomaly. Seawater and precipitates from seawater produce a "W-type" REE pattern: a negative Eu anomaly inherited from the river water and a negative $\mathrm{Ce}$ anomaly resulting from oxidizing conditions in the seawater, which leads to a partial oxidation of $\mathrm{Ce}^{3+}$ and a rapid precipitation of $\mathrm{Ce}^{4+}$. Seawater becomes Ce depleted, and the carbonates formed inherit this anomaly. The deeper the precipitation occurs, the larger the anomaly. Due to the ingestion of old marine carbonates, land snails inherit the corresponding REE pattern.

Mineralogical analysis of the shell matrix revealed the presence of aragonite and calcite. The existence of calcite in the matrix indicates that the original aragonite has undergone reprecipitation as calcite (Pannell 2004). Thus, the chemical and mineralogical analyses of the snail shell reflect the incorporation of old carbon in the form of calcite from the limestone into the shell during its life span and also postmortem, via diagenetic processes. 


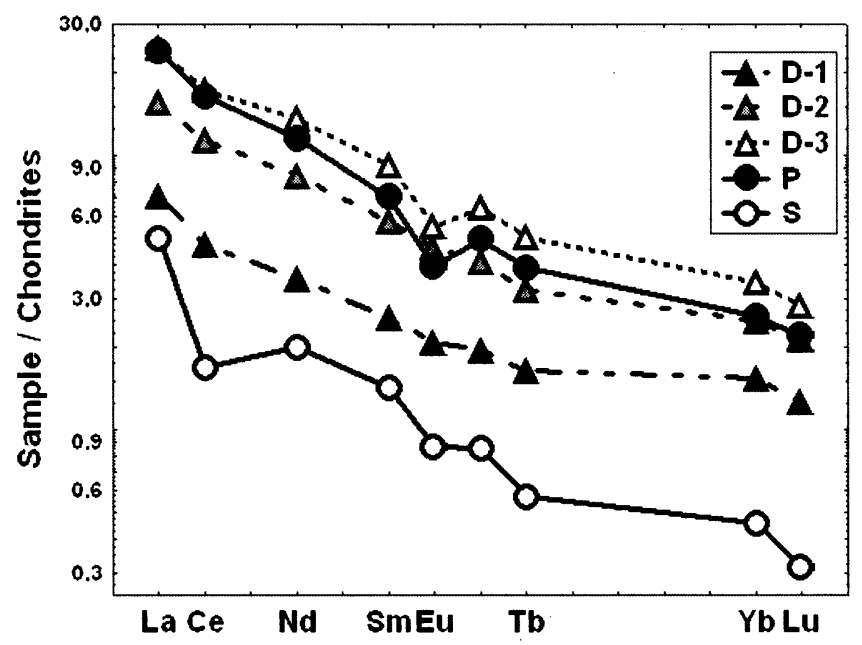

Figure 2 Rare-earth element patterns of paleosol, snail, and dune samples relative to chondrites (Haskin et al. 1971).

The 2 OSL results (samples D-1 and D-2) for the base of the dune (Table 2) are indistinguishable from one another and produce a weighted mean age of 14,420 $\pm 661 \mathrm{yr}$, giving an age range at $2 \sigma$ of 15,742-13,098 yr. The OSL age for the top of the dune (sample D-3) was 11,880 $\pm 537 \mathrm{yr}$, producing a $2-\sigma$ age range of $12,954-10,806$ yr. These data suggest that the dune may have been eventually built up by 2 sand pulses or by remobilization of material on the top during its evolution, prior to consolidation.

\section{CONCLUSIONS}

In this work, it is clearly shown that ${ }^{14} \mathrm{C}$ dating using AMS may not be suitable for sandy soils with a very low organic component $(<1 \%)$, as the age produced was significantly older than that from a blue OSL age measurement made on the same material. Also, ${ }^{14} \mathrm{C}$ dating of land snails found in the sandy soil underneath the Oitavos dune is not appropriate for estimating the age of the paleosol, since the snails lived in a limestone environment and it has been demonstrated that they incorporated old carbon.

The OSL results demonstrate that the upper paleosol material is of a similar age to material at the base of the dune. OSL dating also seems to indicate that the Oitavos dune was formed by diachronic sand pulses or suffered remobilization of material at the top. Its age lies within the interval of $13,098-15,742$ BP for the base and 10,806-12,954 BP for the top (2- $\sigma$ range). Since OSL dating demonstrates that the formation of the Oitavos dune appears to be more complex than expected, further work will have to be undertaken in order to gain a better understanding of the formation processes and its evolution history.

\section{REFERENCES}

Goodfriend GA, Stipp JJ. 1983. Limestone and the problem of radiocarbon dating of land-snail shell carbonate. Geology 11(10):575-7.

Gouveia MA, Prudêncio MI, Freitas MC, Martinho E, Cabral JMP. 1987. Interference from uranium fission products in the determination of rare earths, zirconium and ruthenium by instrumental neutron activation analysis in rocks and minerals. Journal of Radioanalytical and Nuclear Chemistry 114(2):309-18.

Govindaraju K. 1994. Compilation of working values and sample description for 383 geostandards. Geostandards Newsletter 18. Special Issue. p 1-158. 
Haskin LA, Helmke PA, Paster TP, Allen RO. 1971. Rare earths in meteoritic, terrestrial, and lunar matter. In: Brunfelt AO, Steinnes E, editors. Activation Analysis in Geochemistry and Cosmochemistry. Oslo: Universitetsforlaget. p 201-18.

Marques MM, Ramos M. 1983. Note sur les formations dunaires actuelles et fossiles des environs de Lisbonne [Note on the current and fossil dune formations of the surroundings of Lisbon, Portugal]. In: Vidal-Romani JR, Vilas-Martin F, editors. VI Reunion do Grupo Español de Traballo de Quaternário. Cuadernos do Laboratorio Xeolóxico de Laxe 5:597-8. In French.

Moniz C. 1992. Análise de fracturação. Exemplos de aplicação nas dunas consolidadas de Oitavos e Praia da Aguda. Tema das provas de aptidão pedagógica e capacidade científica, Departamento de Geologia (F.C.U.L.). Lisbon: Universidade de Lisboa. In Portuguese.

Pannell CL. 2004. Report on the preliminary gastropod findings from Uamh An Ard Achadh (High Pasture Cave), Kilbride, Strath, Isle of Skye, Scotland (NG
5943 1971). Glasgow: University of Glasgow.

Rebêlo LP. 1998. Dinâmica do sistema dunar do Guincho Oitavos. In: Actas do V Congresso Nacional de Geologia, Lisboa. Comunicações do Instituto Geológico e Mineiro. Tomo 84, Fascículo 1, C83-C84. In Portuguese.

Rebêlo LP. 2004. Evolução e dinâmica dos sistemas dunares da Manta Rota e do Guincho-Oitavos: dois sistemas distintos na Evolução das dunas costeiras em Portugal [PhD dissertation]. Dissertação referente às provas de acesso à categoria de Investigador Auxiliar do Instituto Geológico e Mineiro (IGM). Alfragide: IGM. 205 p. In Portuguese.

Richter D, Zink AJC, Przegietka KR, Cardoso GO, Gouveia MA, Prudêncio MI. 2003. Source calibrations and blind test results from the new Luminescence Dating Laboratory at the Instituto Tecnológico e Nuclear, Sacavém, Portugal. Ancient TL 21(1):43-8.

Slota Jr PJ, Jull AJT, Linick TW, Toolin LJ. 1987. Preparation of small samples for ${ }^{14} \mathrm{C}$ accelerator targets by catalytic reduction of CO. Radiocarbon 29(2):303-6. 